TRIDHARMADIMAS: Jurnal Pengabdian Kepada Masyarakat Jayakarta

http://journal.stmikjayakarta.ac.id/index.php/tridharmadimas

EmaiL: info@stmik.jayakarta.ac.id , tridharmadimas.jayakarta@gmail.com

E-ISSN: 2798-8295 (Online), P-ISSN: 2798-8554 (Print) Vol. 1 No.1, Juli 2021

DOI : https://doi.org/10.52362/tridharmadimas.v1i1.494 Halaman 9-18

\title{
MEMBANGKITKAN UMKM DI TENGAH PANDEMI COVID 19.
}

\author{
Winda Suci Lestari Nasution $^{1 *}$, Patriot Nusa ${ }^{2}$, Syahrizal Dwi Putra ${ }^{3}$ \\ ${ }^{1}$ Universitas Esa Unggul \\ ${ }^{2}$ Politeknik Perdana Mandiri Purwakarta \\ ${ }^{3}$ Universitas Esa Unggul \\ *winda.suci@esaunggul.ac.id*patriotnusa@gmail.com*syahrizal.dwi@esaunggul.ac.id
}

\begin{abstract}
ABSTRAK. Usaha Mikro, Kecil dan Menengah (UMKM) merupakan salah satu unit usaha yang berperan penting dalam pertumbuhan dan perkembangan perekonomian di Indonesia. UMKM juga merupakan salah satu penyokong perekonomian di Indonesia khususnya pada masyarakat golongan bawah dan menengah. UMKM memiliki peran strategis dalam upaya pemerintah dalam mengatasi kemiskinan dan pengangguran, karena UMKM dapat menyerap tenaga kerja sehingga pengangguran akibat tidak terserapnya angkatan kerja dalam dunia kerja menjadi berkurang. Pandemi Covid-19 yang terjadi melanda seluruh dunia, secara global, termasuk Indonesia, tentu saja berdampak terhadap berbagai sektor terutama di sektor ekonomi. Himbauan untuk mencegah mata rantai penyebaran virus ini mengharuskan masyarakat untuk berdiam diri di rumah dan mengurangi kegiatan di luar rumah. Semua sendi kehidupan terpengaruhi dan dipaksa untuk mengubah pola hidup, pola kerja, pola berpikir dan polapola lain yang dijalankan manusia. Dampak negatif akibat pandemi COVID-19 ini telah menghambat pertumbuhan UMKM. Indonesia yang didominasi oleh UMKM sebagai tulang punggung perekonomian nasional terdampak oleh adanya pandemi COVID-19, bukan hanya pada aspek produksi dan pendapatan saja namun juga pada jumlah tenaga kerja yang harus dikurangi dan lain-lain. UMKM kurang memiliki ketahanan dan fleksibilitas dalam menghadapi pandemi COVID-19 ini dikarenakan beberapa hal seperti tingkat digitalisasi yang masih rendah, kesulitan dalam mengakses teknologi dan kurangnya pemahaman tentang strategi bertahan dalam bisnis.
\end{abstract}

Kata kunci: UMKM; perekonomian: covid 19

ABSTRACT. Micro, Small and Medium Enterprises (MSMEs) are one of the business units that play an important role in economic growth and development in Indonesia. MSMEs are also one of the supporters of the economy in Indonesia, especially for the lower and middle class people. MSMEs have a strategic role in the government's efforts to overcome poverty and unemployment, because MSMEs can absorb labor so that unemployment due to not absorbing the labor force in the world of work is reduced. The Covid-19 pandemic that has hit the whole world, globally, including Indonesia, of course has an impact on various sectors, especially in the economic sector. The call to prevent the chain of spreading this virus requires people to stay at home and reduce activities outside the home. All aspects of life are affected and forced to change the pattern of life, work patterns, thinking patterns and other patterns that humans run. The negative impact of the COVID-

This work is licensed under a Creative Commons Attribution-NonCommercial-ShareAlike 4.0 International License. 
19 pandemic has hampered the growth of MSMEs. Indonesia, which is dominated by MSMEs as the backbone of the national economy, is affected by the COVID-19 pandemic, not only in terms of production and income but also in the number of workers that must be reduced and others. MSMEs lack resilience and flexibility in dealing with the COVID-19 pandemic due to several things, such as the low level of digitalization, difficulties in accessing technology and a lack of understanding of strategies to survive in business.

Keywords: MSMEs; economy; covid 19

\section{PENDAHULUAN}

Usaha Mikro, Kecil dan Menengah (UMKM) merupakan salah satu unit usaha yang berperan penting dalam pertumbuhan dan perkembangan perekonomian di Indonesia. UMKM juga merupakan salah satu penyokong perekonomian di Indonesia khususnya pada masyarakat golongan bawah dan menengah. (Thaha, 2020). UMKM memiliki peran strategis dalam upaya pemerintah dalam mengatasi kemiskinan dan pengangguran, karena UMKM dapat menyerap tenaga kerja sehingga pengangguran akibat tidak terserapnya angkatan kerja dalam dunia kerja menjadi berkurang. Diawal tahun 2020, serangan pandemi COVID-19 telah memicu sentimen negatif terhadap berbagai lini bisnis khususnya bisnis UMKM. Dampak negatif akibat pandemi COVID-19 ini telah menghambat pertumbuhan UMKM (Pudyastiwi, Elisabeth S.H. \& Djatmiko,Agoes S.H., 2020). Indonesia yang didominasi oleh UMKM sebagai tulang punggung perekonomian nasional terdampak oleh adanya pandemi COVID-19, bukan hanya pada aspek produksi dan pendapatan saja, namun juga pada jumlah tenaga kerja yang harus dikurangi dan lain-lain.(Arianto, 2020) UMKM kurang memiliki ketahanan dan fleksibilitas dalam menghadapi pandemi COVID-19 ini dikarenakan beberapa hal seperti tingkat digitalisasi yang masih rendah, kesulitan dalam mengakses teknologi dan kurangnya pemahaman tentang strategi bertahan dalam bisnis. (Bahtiar \& Saragih, 2020)

\section{Dampak Pandemi}

Dampak yang terjadi di belahan dunia dan Indonesia :

1. Banyak orang takut keluar rumah

2. Khawatir dengan masalah keuangan

3. Pertemuan antar orang menjadi terbatas 
TRIDHARMADIMAS: Jurnal Pengabdian Kepada Masyarakat Jayakarta

http://journal.stmikjayakarta.ac.id/index.php/tridharmadimas

EmaiL: info@stmik.jayakarta.ac.id , tridharmadimas.jayakarta@gmail.com

E-ISSN: 2798-8295 (Online), P-ISSN: 2798-8554 (Print) Vol. 1 No.1, Juli 2021

DOI : https://doi.org/10.52362/tridharmadimas.v1i1.494

Halaman 9-18

4. Banyak karyawan dirumahkan (PHK)

5. Perilaku masyarakat berubah dari biasanya (Abidin Achmad et al., 2020)

\section{Dampaknya Terhadap Dunia Wirausaha}

- Pasar Lesuh

- Distribusi Terhambat

- Omzet Turun Drastis

- Modal Terganggu

- Kredit Macet

- Bahan Baku Apkir

\section{METODE}

Pengabdian masyarakat yang kami lakukan di wadahi oleh LED international dan semua anggota Asosiasi Dosen Indonesia (ADI) yang terdiri dari kolaborasi beberapa universitas terkemuka di wilayah DKI Jakarta. Adapun daftar peserta kegiatan ini terdiri dari beberapa institusi antara lain adalah : Universitas Esa Unggul, Universitas Persada Indonesi Y.A.I, Universitas Tama Jagakarsa, Universitas Pamulang, Universitas Mitra Indonesia, Universitas Mercubuana, Universitas Suryadarma, Sekolah Tinggi Manajemen PPM, Universitas Budi Luhur, Universitas Darma Persada, Universitas IndraPrasta PGRI, Bina Sarana Informatika, danSTMIK Antar Bangsa. Pelaksanaan kegiatan Pengabdian kepada Masyarakat ini berbentuk pelatihan yang dilakukan secara daring melalui zoom mengenai bagaimana membangkitkan UMKM di tengah pandemic Covid 19 sebagai pendukung branding dan inovasi serta packing atas produk-produk sehingga mampu bersaing di medan dunia online pada aplikasinya melalui webiner dengan menggunakan zoom. Adapun tahapan yang dilalui terdiri dari :

1. Analisis Kebutuhan yaitu kebutuhan penyuluhan merupakan alat untuk memberikan pengetahuan memetakan pelatihan dan pengembangan kebutuhan branding untuk menumbuhkan bakat di tingkat manapun dalam bisnis untuk memenuhi kebutuhan bisnis di tahun mendatang 
2. Perencanaan yaitu mempersiapkan materi pelatihan, alat-alat dan bahan yang diperlukan untuk kegiatan pelatihan sebagai upaya mendukung cara branding dan inovasi serta packing atas produk-produk.

3. Pelaksanaan yaitu memberikan pengenalan kepada para UMKM terkait optimalisasi branding dan inovasi serta packing atas produk-produk khususnya dalam penyampaian materi-materi bahan pendukung baik berupa file PPT, link dan juga video pelatihan.

Kegiatan ini dilakukan pada hari Rabu 24 Januari 2021 menggunakan Zoom sebagai perantaranya. Maka tidak ada pertemuan fisik secara langsung diantara pemateri dan para UMKM. Mitra dari kegiatan pengabdian pada masyarakat kali ini adalah para UMKM yang terdiri dari beragam jenis usaha yang bedomisili disekitar wilayah Jakarta dan sekitarnya. Sasaran kegiatan ini berupa pengetahuan mengenai bagaimana mengubah branding dunia nyata pada kondisi normal menjadi branding di medan online.

\section{HASIL DAN PEMBAHASAN}

Secara umum, hasil dan luaran yang dihasilkan kegiatan ini mencakup dibentuknya sebuah bahan e-commerce, digital marketing, memperbaiki kualitas produk serta costumer relationship marketing sebagai media yang memberikan pemahaman dalam penyampaian file presentasi, link, bahan teori serta video branding. Ditambah lagi bahwa digital marketing yang baik dapat meningkatkan penjualan di saat pandemic seperti saat ini. Dari beberapa hal tersebut, ada beberapa hal penting yang harus menjadi perhatian yaitu sumber tenaga sinyal di lokasi UMKM pada berbagai kondisi dengan segala kelebihan dan kekurangan sumber daya pada lokasi UMKM sehingga diharapkan proses penjualan dengan branding dan inovasi serta packing atas produk-produk mampu bersaing dalam berbagai kondisi.

Sebelum pelaksanaan, tim abdimas melakukan komunikasi ke pihak UMKM di wilayah Jakarta. Para UMKM tersebut merupakan ibu-ibu rumah tangga yang melakukan kegiatan perdagangan di 
pasar ataupun suatu lokasi sebagai lokasi warung ataupun keda mereka. Akan tetapi sejak pandemic global ini terpaksa mereka melakukan kegiatan berdagang hanya dari rumah. Dari hasil diskusi tersebut, para UMKM menganjurkan untuk memberikan pelatihan yang ada kaitannya dengan branding dan inovasi serta packing atas produk-produk sehingga mampu bersaing di medan dunia online. Dari hasil tersebut kami memutuskan bentuk kegiatan dengan pengenalan dan penyuluhan melalui webiner dengan menggunkan zoom dengan agar para UMKM dapat memahami bagaimana membuat branding dan inovasi serta packing atas produk-produk sehingga mampu bersaing di medan dunia online.

\section{Pemaparan Materi Pelatihan}

Pada sesi pemaparan materi pelatihan kegiatan abdimas ini dimulai dengan melakukan tes awal pemahaman peserta UMKM terhadap materi yang akan disampaikan. Beberapa peserta UMKM banyak yang belum mengetahui cara branding dan inovasi serta packing atas produk-produk sehingga mampu bersaing di medan dunia online. Berikut ini gambaran IPTEKS yang ditransfer dapat dijelaskan pada gambar berikut.

\section{Gambar 1. Gambaran IPTEKS yang ditransfer}

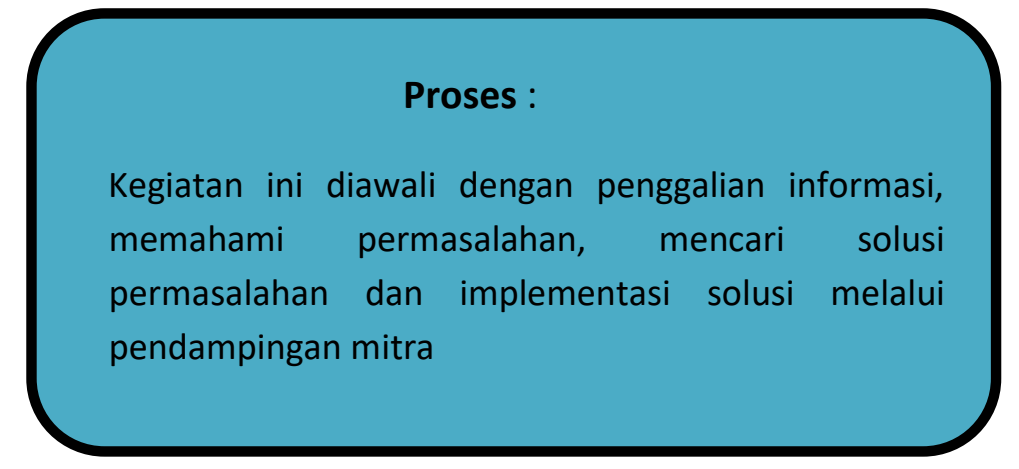

This work is licensed under a Creative Commons Attribution-NonCommercial-ShareAlike 4.0 International License. 
TRIDHARMADIMAS: Jurnal Pengabdian Kepada Masyarakat Jayakarta

http://journal.stmikjayakarta.ac.id/index.php/tridharmadimas

EmaiL: info@stmik.jayakarta.ac.id , tridharmadimas.jayakarta@gmail.com

E-ISSN: 2798-8295 (Online), P-ISSN: 2798-8554 (Print) Vol. 1 No.1, Juli 2021

DOI : https://doi.org/10.52362/tridharmadimas.v1i1.494 Halaman 9-18

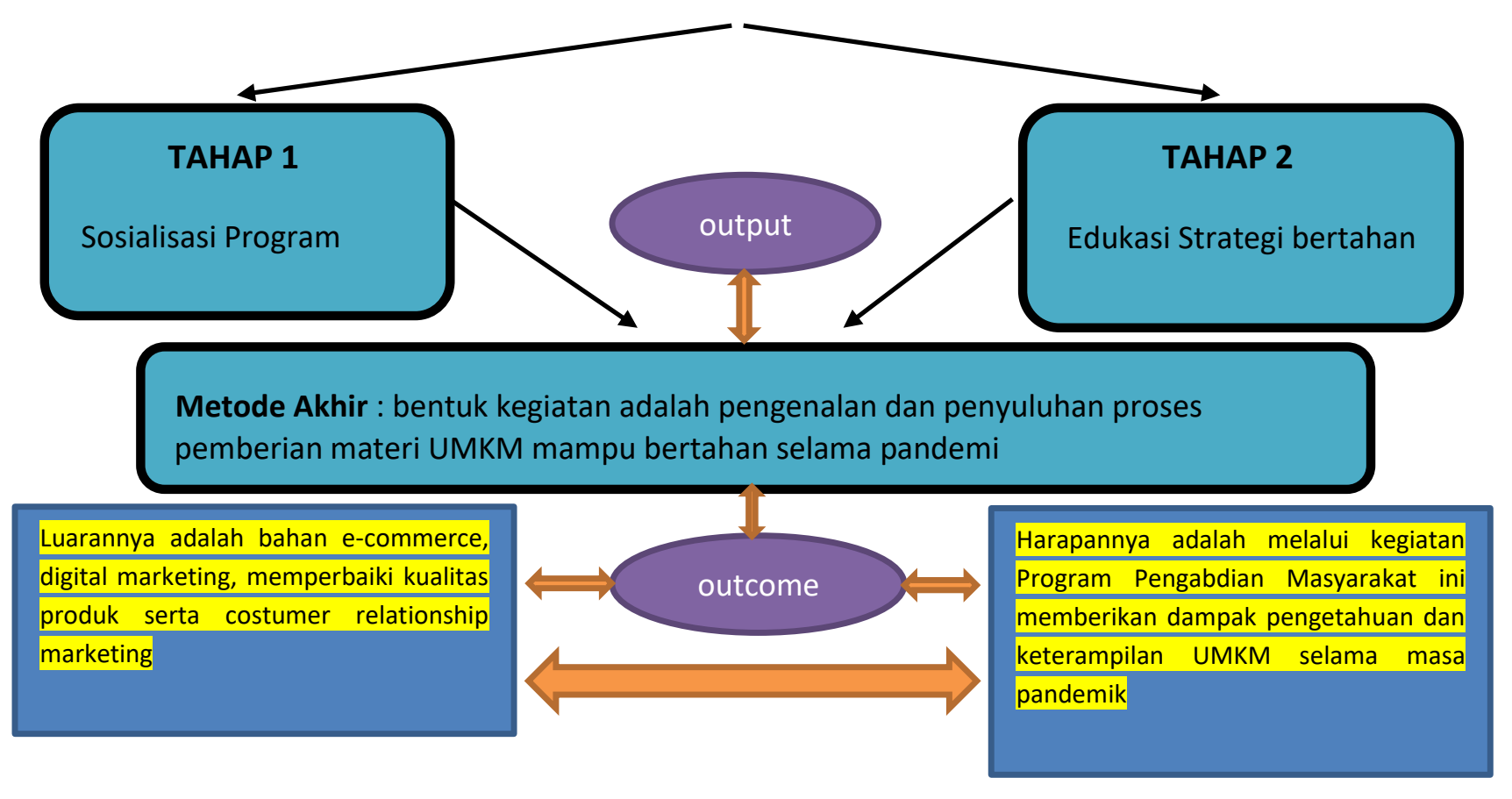

Pada pemaparan materi, instruktur menjelaskan tentang pemanfaatan digital dengan cara branding dan inovasi serta packing atas produk-produk. Untuk mengatasi masalah pemahaman diatas, maka pengenalan proses branding dan inovasi serta packing atas produk-produk dilaksanakan. Masalah peningkatan kualitas sumber daya manusia. Untuk mengatasi masalah peningkatan kualitas sumber daya manusia perlu adanya workshop singkat yang dapat dipahami oleh mitra dalam rangka meningkatkan kualitas sumber daya manusia tersebut.

Kegiatan ini diawali dengan penggalian informasi, memahami permasalahan, mencari solusi permasalahan dan implementasi solusi melalui pendampingan mitra. Harapannya adalah melalui kegiatan Program Pengabdian Masyarakat ini memberikan dampak pengetahuan dan keterampilan para guru dalam membangkitkan UMKM di tengah pandemic covid 19.

This work is licensed under a Creative Commons Attribution-NonCommercial-ShareAlike 4.0 International License. 
TRIDHARMADIMAS: Jurnal Pengabdian Kepada Masyarakat Jayakarta http://journal.stmikjayakarta.ac.id/index.php/tridharmadimas EmaiL: info@stmik.jayakarta.ac.id , tridharmadimas.jayakarta@gmail.com E-ISSN: 2798-8295 (Online), P-ISSN: 2798-8554 (Print) Vol. 1 No.1, Juli 2021 DOI : https://doi.org/10.52362/tridharmadimas.v1i1.494 Halaman 9-18

Gambar 2. Pelaksanaan Pelatihan Daring melalui Video Conference
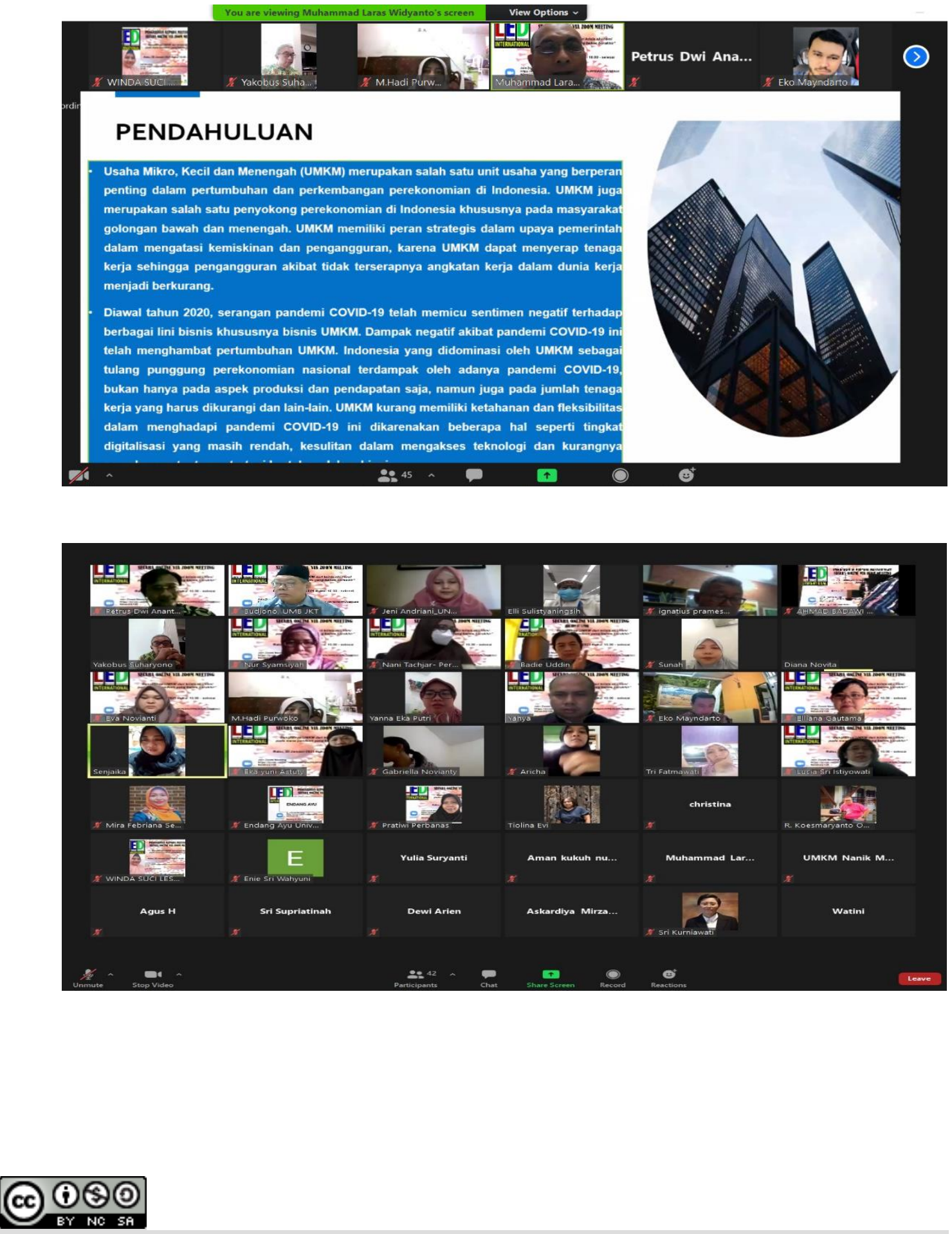

This work is licensed under a Creative Commons Attribution-NonCommercial-ShareAlike 4.0 International License. 
Diskusi berlanjut mengenai cara branding yang menarik, menyolok di mata dan telinga, sehingga menempel di kepala calon pembeli dan publik secara luas. Zaman sudah berubah, dengan penggunaan teknologi produk UMKM dapat lebih kompetitif di pasar. Secara khusus pengaplikasian branding produk diterapkan pada sehingga keunggulan-keunggulan produk dapat dikomunikasikan.

\section{Praktek Mandiri}

Setelah selesai melaksanakan pelatihan dan tutorial dari instruktur, maka dilanjutkan dengan praktek mandiri. Pada praktek mandiri ini, peserta UMKM diberikan materi berupa vidio praktek yang bertujuan agar peserta UMKM dapat melanjutkan cara branding dan inovasi serta packing atas produkproduk secara mandiri.

Kegiatan pengabdian masyarakat ini memberikan hasil sebagai berikut:

1. Peserta dapat memahami konsep branding dan inovasi serta packing atas produk-produk.

2. Peserta dapat memahami tahapan dalam membuat branding dan inovasi serta packing atas produkproduk

3. Peserta dapat memahami tahapan dalam memperbaiki branding dan inovasi

4. Peserta dapat memahami pelaksanaan branding dan inovasi serta packing produk secara online dengan memanfaatkan bahan e-commerce, digital marketing dan memperbaiki kualitas produk serta costumer relationship marketing

\section{KESIMPULAN}

Pandemi COVID-19 yang terjadi di Indonesia berdampak pada ketidakstabilan dalam perekonomian terutama pada UMKM. Pelaku UMKM merasakan dampak langsung berupa penurunan omset penjualan dikarenakan adanya himbauan pemerintah dan penerapan PSBB yang menghimbau masyarakat untuk tetap dirumah sehingga cukup banyak UMKM yang harus berenti beroperasi untuk sementara waktu. Dalam kondisi seperti saat ini, bantak tantangan yang harus dihadapi oleh para pelaku UMKM. Untuk itu pelaku UMKM harus memiliki strategi untuk dapat bertahan di tengah pandemi ini dan dituntut untuk dapat menyesuaikan diri terhadap kondisi yang terjadi, sehingga dapat mengubah

This work is licensed under a Creative Commons Attribution-NonCommercial-ShareAlike 4.0 International License. 
tantangan yang ada menjadi peluang. Terdapat beberapa strategi yang dapat di lakukan UMKM untuk dapat mempertahankan bisnisnya, yaitu

a. melakukan penjualan melalui e-commerce.

b. Melakukan pemasaran produk dengan memanfaatkan teknologi digital (digital marketing).

c. melakukan perbaikan kualitas produk dan kualitas serta jenis layanan.

d. Melakukan pemasaran hubungan pelanggan (customer relationship marketing).

\section{SARAN}

Saran yang dapat direkomendasikan adalah para pelaku UMKM harus memiliki strategi ataupun menerapkan strategi yang telah dijelaskan untuk dapat bertahan di tengah pandemi ini dan dituntut untuk dapat menyesuaikan diri terhadap kondisi yang terjadi., sehingga dapat mengubah tantangan yang ada menjadi peluang. Karena UMKM yang dapat bertahan adalah UMKM yang responsif terhadap perubahan sekitar dan mampu menyesuaikan diri baik dari segi produk, sistem pemasaran dan penjualan maupun penggunaan teknologi yang mendukung bisnis. Selain itu, perlu adanya dukungan ataupun dorongan dari pemerintah dalam mwujudkan pengembangan UMKM di tengah pandemi COVID-19.

\section{UCAPAN TERIMAKASIH}

Penulis mengucapkan terima kasih kepada LED international dan semua anggota Asosiasi Dosen Indonesia (ADI) yang terdiri dari kolaborasi beberapa universitas terkemuka di wilayah DKI Jakarta yakni Universitas Esa Unggul, Universitas Persada Indonesi Y.A.I, Universitas Tama Jagakarsa, Universitas Pamulang, Universitas Mitra Indonesia, Universitas Mercubuana, Universitas Suryadarma, Sekolah Tinggi Manajemen PPM, Universitas Budi Luhur, Universitas Darma Persada, Universitas IndraPrasta PGRI, Bina Sarana Informatika, danSTMIK Antar Bangsa. sehingga pengabdian masyarakat ini dapat diselesaikan dengan baik.

\section{(c) (1) (ㅇ)}

This work is licensed under a Creative Commons Attribution-NonCommercial-ShareAlike 4.0 International License. 


\section{DAFTAR PUSTAKA}

[1] Abidin Achmad, Z., Zendo Azhari, T., Naufal Esfandiar, W., Nuryaningrum, N., Farah Dhilah Syifana, A., \& Cahyaningrum, I. (2020). Pemanfaatan Media Sosial dalam Pemasaran Produk UMKM di Kelurahan Sidokumpul, Kabupaten Gresik. Jurnal Ilmu Komunikasi. https://doi.org/10.15642/jik.2020.10.1.17-31

[2] Arianto, B. (2020). Pengembangan UMKM Digital di Masa Pandemi Covid-19. ATRABIS: Jurnal Administrasi Bisnis.

[3] Bahtiar, R. A., \& Saragih, J. P. (2020). Dampak Covid-19 terhadap perlambatan ekonomi sektor umkm. Jurnal Bidang Ekonomi Dan Kebijakan Publik.

[4] Pudyastiwi, Elisabeth S.H., M. ., \& Djatmiko,Agoes S.H., M. . (2020). USAHA MIKRO, KECIL DAN MENENGAH (UMKM) INDONESIA DALAM MENGHADAPI PERDAGANGAN BEBAS DI ASEAN. Jurnal Pendidikan Kewarganegaraan Undiksha.

[5] Thaha, A. F. (2020). Dampak Covid-19 Terhadap UMKM di Indonesia. Jurnal Brand. 